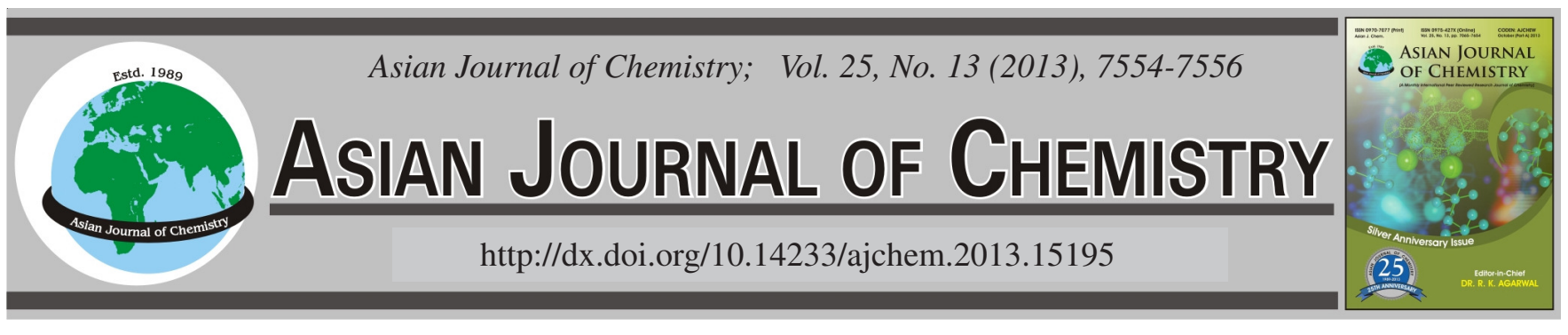

\title{
Distribution and Health Risk Assessment of Total Petroleum Hydrocarbon in a Gas Station Contaminated Site in Chongqing, China
}

\author{
Shaojie JiAng ${ }^{1, *}$, Ying Zhang $^{1}$, Ping $\mathrm{XIANG}^{1}$ and PeiYu Huang ${ }^{2}$
}

${ }^{1}$ Key Laboratory of the Three Gorges Reservoir Region's Eco-Environment, Ministry of Education, Chongqing University, Chongqing 400045, P.R. China

${ }^{2}$ Mei Tian Environmental Protection Company, Chongqing 400045, P.R. China

*Corresponding author: E-mail: 303438903@qq.com

(Received: 22 January 2013;

Accepted: 1 July 2013)

AJC-13750

\begin{abstract}
The total petroleum hydrocarbon contamination of gas stations has now become a serious environmental issue on the global scale. In this paper, investigation and human risk assessment of soil contamination was undertaken in a typical gas station in Chongqing. The results indicated that the site soil was polluted by total petroleum hydrocarbon to various extents and concentrations of some points were far beyond the critical value of intervention basing on Dutch standard, oil spilled from tank or oil leaked from underground oil storage are supposed to must be the main contributing source. Unfortunately, this site would be planed to utilize for residential land use. The residents would have great health risk on account of the long-term exposure to total petroleum hydrocarbons. Therefore, contaminate site should be remediated before construction as the residential area.
\end{abstract}

Key Words: Gas station, Total petroleum hydrocarbon, Contaminated site, Risk assessment.

ᄂ - - - - - - - - - - - - - - - - - - - - - - - - - - - - - - - -

\section{INTRODUCTION}

Comparing with other industry wastewater discharge, the pollution of soil and underground water by gas station leaking or leakage from underground soil tanks is more difficult to determine, if these happen, it will lead to grave consequence ${ }^{1}$. The US EPA took an investigation about the underground tanks built before September 2001, it indicated that there are 420,000 leaking tanks and nearly 150,000 of which need remediation ${ }^{2}$. Shell' investigation found that over 1,100 gas stations leaking oil had lead to severe soil and underground water pollution in the UK. Similar pollution in the Czech Republic, Hungary, the former Soviet Union and South America had also been reported ${ }^{1}$.

China also were troubled by soil and groundwater contamination. Such as Anjulou and Liuliqiao gas station leakage issues in Beijing, water plant had to stop supplying water for a long time, the residents within 36 square kilometers were cut off the water. Earlier in 1998, some analysis on soil and groundwater nearby gas station were carried out in Tianjin. It showed that the maximum value of permanganate index has exceeded the national standard value of groundwater Class IV $(10 \mathrm{mg} / \mathrm{L})$; the maximum value of ammonia was two times higher compared to the national control standard $(0.5 \mathrm{mg} / \mathrm{L})$; total petroleum hydrocarbons were determined in most samples, the concentration of benzene, toluene, ethylbenzene and xylene were low and carcinogens such as polycyclic aromatic hydrocarbons (PAHs) were detected in most samples.

Soil contamination nearby gas station had gradually become prominent site in China as well as pesticide-contaminating sites. However, there is still no corresponding standard for petroleum hydrocarbon contamination assessment in china. This study was to develop an reference approach for assessment soil contamination by total petroleum hydrocarbon (TPH) and a case study was introduced and the soil and subsoil in a gas station in Chongqing were investigated, last but not the least, the residents' health risk results from TPH was to be evaluated $^{3-7}$.

\section{EXPERIMENTAL}

The gas station locates in Yuzhong district of Chongqing, where is in the subtropical humid monsoon climate zone, influenced by the special topography, so, it is famous for high temperatures, less sunshine, long rainy season, humidity, cloudy, less frost and wind. Annually, the average temperature was $18.4{ }^{\circ} \mathrm{C}$ and average relative humidity was $80 \%$, the average rainfall was $1151.5 \mathrm{~mm}$, annual sunshine time was $1140.5 \mathrm{~h}$, annual average number of foggy days were 43 days, the annual average wind speed was $1.5 \mathrm{~m} / \mathrm{s}$, the dominant wind direction and frequency was NNE of $12 \%$. The surface soil in Yuzhong district mostly is clay and sandy clay, covering the bedrock, mainly cetaceous sandstone and clay shale. The clay 
mainly is yellowish-brown and purple-brown clay, low porosity and low permeability. In the sandy clay, groundwater occasionally was found, the main source is precipitation and there is no large-scale shallow groundwater and the geological structure is stable, no adverse geological phenomena such as landslides has been recorded.

In this study, $40 \mathrm{~m} \times 40 \mathrm{~m}$ grid cloth was employed for optimizing sampling point, 13 monitoring sample sites were as shown in Fig. 1 (Table-1). For each well, soil samples were from the depth of underground $0.5-1.0 \mathrm{~m}$, underground 1.0 $2.0 \mathrm{~m}$, underground $2.0-3.0 \mathrm{~m}$, underground $3.0-4.0 \mathrm{~m}$, underground 4.0-5.0 $\mathrm{m}$ and underground 5.0-6.0 m. In order to ensure the accuracy of determination, especially for VOC, manual, mechanical sampling and the Geoprobe rig system for parallel sampling were utilized with on-site package. $\mathrm{Pb}$ (due to its correlation to gasoline) and $\mathrm{Hg}$ (due to its volatility) were listed as monitoring items of total petroleum hydrocarbon.

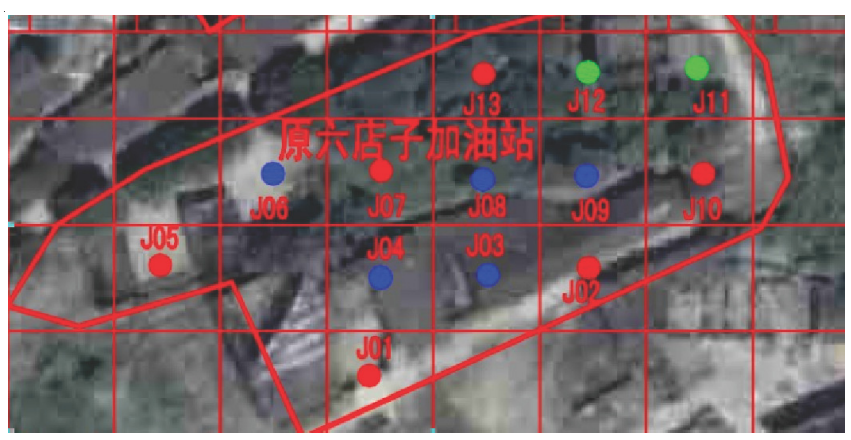

Fig. 1. Layout of sampling. One gas station in Yuzhong

This gas station was used for feeding gasoline and diesel. So our emphasis was TPH assay, then gas chromatography was employed to determine typical samples and residual pollutants of area where industry residual mixed soil.

Human health risk assessment model was as followed:

Exposure assessment: Direct ingestion of contaminated

$$
\mathrm{EDI}_{\mathrm{INGES}}=\frac{\mathrm{CS} \times \mathrm{IR} \times \mathrm{CF} \times \mathrm{EF} \times \mathrm{ED}}{\mathrm{BW} \times \mathrm{AT}}
$$

Dermal intake

$$
\mathrm{EDI}_{\mathrm{DER}}=\frac{\mathrm{CS} \times \mathrm{CF} \times \mathrm{SA} \times \mathrm{AF} \times \mathrm{ABS} \times \mathrm{EF} \times \mathrm{ED}}{\mathrm{BW} \times \mathrm{AT}}
$$

Inhalation of soil dust through the respiratory system

$$
\mathrm{EDI}_{\mathrm{INHALE}}=\frac{\mathrm{CS} \times(1 / \mathrm{PEF}) \times \mathrm{IR} \times \mathrm{EF} \times \mathrm{ED}}{\mathrm{BW} \times \mathrm{AT}}
$$

where: EDI is inhaled (direct inhaled), $\mathrm{mg} /(\mathrm{kg} \mathrm{d})$; $\mathrm{CS}$ is the concentration of chemical substances in soil, $\mathrm{mg} / \mathrm{kg}$; IR soil intake, $\mathrm{mg} / \mathrm{d}$; $\mathrm{CF}$ is conversion factor, $\mathrm{kg} / \mathrm{mg}$; $\mathrm{SA}$ as a possible skin contact with the soil area, $\mathrm{cm}^{2} / \mathrm{d}$; AF on the skin for the soil adsorption coefficient, $\mathrm{mg} / \mathrm{cm}^{2}$; ABS skin absorption coefficient; EF is exposure frequency, d/a; ED is exposure period, a; PEF generated soil dust factor, $\mathrm{m}^{3} / \mathrm{kg}$; BW is body weight, $\mathrm{kg}$; AT is the average reaction time, $\mathrm{d}$.

Non-carcinogenic risk: The potential non-carcinogenic risks of contaminated sites should be used by health risk Entropy. Heath Risk risk = exposure dose/reference dose. In general, if the value exceeds ${ }^{1}$, it indicates that there exists unacceptable potentially non-carcinogenic effects. The non-carcinogenic effects (reference dose) of TPH are show in Table-2.

\section{RESULTS AND DISCUSSION}

Lead, mercury and total petroleum hydrocarbons were monitored in this research. Monitoring results were as shown as Figs. 2-5.

Monitoring results (Figs. 2-4) indicated that the samples' concentrations of lead, mercury did not exceed the limit of the <Soil environmental quality standard $>$ (GB15618-1995), while TPH of the labeled J09-2, J10-2 and J12-1 samples exceeded the critical intervention value of Dutch standard. Because the sampling site of labeled \# 9 was the location of storage tanks, it could conclude that grave total petroleum

\begin{tabular}{|c|c|c|c|c|c|}
\hline \multicolumn{6}{|c|}{$\begin{array}{c}\text { TABLE-1 } \\
\text { MONITORING COORDINATION AND POSITION }\end{array}$} \\
\hline Point & Type & Coordinate & Depth $(\mathrm{m})$ & Number & Subject \\
\hline $\mathrm{J} 01$ & Surface & $\mathrm{X}=56985.8208, \mathrm{Y}=67691.5446$ & 4 & 5 & $\mathrm{~Pb}, \mathrm{Hg}, \mathrm{TPH}$ \\
\hline J02 & Surface & $X=57027.0032, Y=67711.8688$ & 4 & 5 & $\mathrm{~Pb}, \mathrm{Hg}, \mathrm{TPH}$ \\
\hline J03 & Bottom & $X=57008.1824, Y=67710.5996$ & 8 & 5 & $\mathrm{~Pb}, \mathrm{Hg}, \mathrm{TPH}$ \\
\hline J04 & Bottom & $X=56988.0115, Y=67710.4409$ & 8 & 5 & $\mathrm{~Pb}, \mathrm{Hg}, \mathrm{TPH}$ \\
\hline J05 & Surface & $X=56946.5807, Y=67712.4928$ & 4 & 5 & $\mathrm{~Pb}, \mathrm{Hg}, \mathrm{TPH}$ \\
\hline J06 & Bottom & $X=56967.6292, Y=67729.5986$ & 8 & 5 & $\mathrm{~Pb}, \mathrm{Hg}, \mathrm{TPH}$ \\
\hline J07 & Surface & $X=56988.0864, Y=67730.0985$ & 9 & 5 & $\mathrm{~Pb}, \mathrm{Hg}, \mathrm{TPH}$ \\
\hline J08 & Bottom & $X=57007.1673, Y=67728.4737$ & 9 & 5 & $\mathrm{~Pb}, \mathrm{Hg}, \mathrm{TPH}$ \\
\hline J09 & Bottom & $X=57026.6923, Y=67729.1740$ & 9 & 5 & $\mathrm{~Pb}, \mathrm{Hg}, \mathrm{TPH}$ \\
\hline $\mathrm{J} 10$ & Surface & $X=57048.5165, Y=67729.3844$ & 4 & 5 & $\mathrm{~Pb}, \mathrm{Hg}, \mathrm{TPH}$ \\
\hline $\mathrm{J} 11$ & Bottom & $X=57047.5007, Y=67749.3431$ & 8 & 5 & $\mathrm{~Pb}, \mathrm{Hg}, \mathrm{TPH}$ \\
\hline $\mathrm{J} 12$ & Bottom & $X=57026.9480, Y=67748.6237$ & 9 & 5 & $\mathrm{~Pb}, \mathrm{Hg}, \mathrm{TPH}$ \\
\hline $\mathrm{J} 13$ & Surface & $X=57007.3730, Y=67748.2870$ & 4 & 5 & $\mathrm{~Pb}, \mathrm{Hg}, \mathrm{TPH}$ \\
\hline
\end{tabular}
soil

TABLE-1

TABLE-2

TEST METHODS OF SAMPLES

\begin{tabular}{ccccc}
\hline No. & Subject & Standard & Method & Minimum limit (mg/kg) \\
\hline 1 & $\mathrm{~Pb}$ & GB/T17140-1997 & Flame atomic absorption spectrophotometry \\
2 & $\mathrm{Hg}$ & GB/T17136-1997 & Cold vapour atomicabsorption spectrophotometry & 0.0005 \\
3 & $\mathrm{TPH}$ & HJ350-2007 & GC & 5.00 \\
\hline
\end{tabular}


TABLE-3

REFERENCE CALCULATION PARAMETERS OF EXPOSURE

\begin{tabular}{cccccccccccc}
\hline Parameter & IR & CF & SA & AF & ABS & EF & ED & PEF & BW & AT \\
\hline Value & 5 & $10^{-6}$ & 1800 & 1 & 0.1 & 350 & 6 & $1.32 \times 10^{9}$ & 15 & 2190 \\
\hline
\end{tabular}

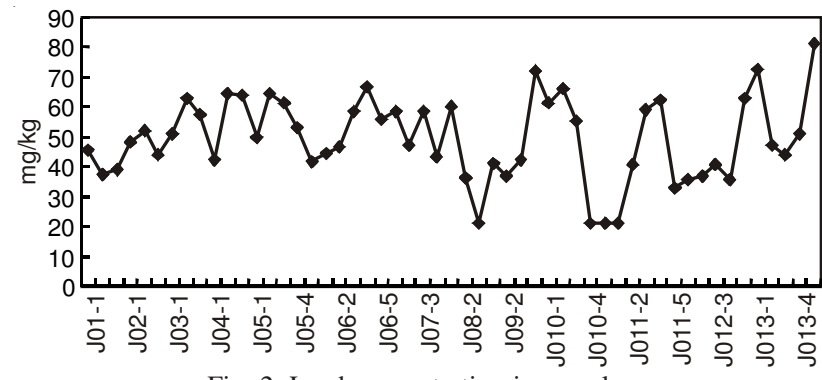

Fig. 2. Lead concentration in samples

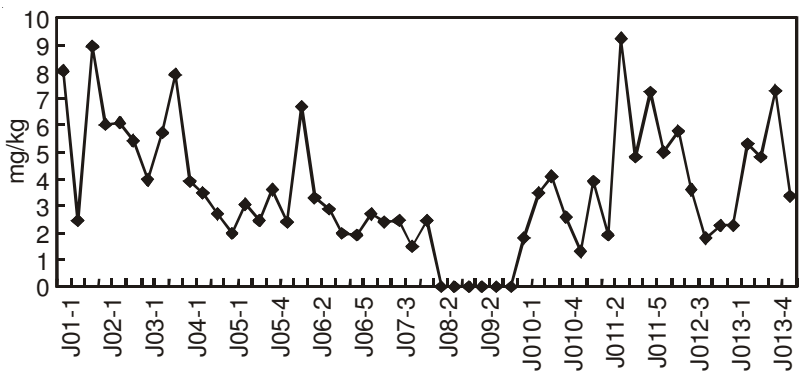

Fig. 3. Mercury concentration in samples

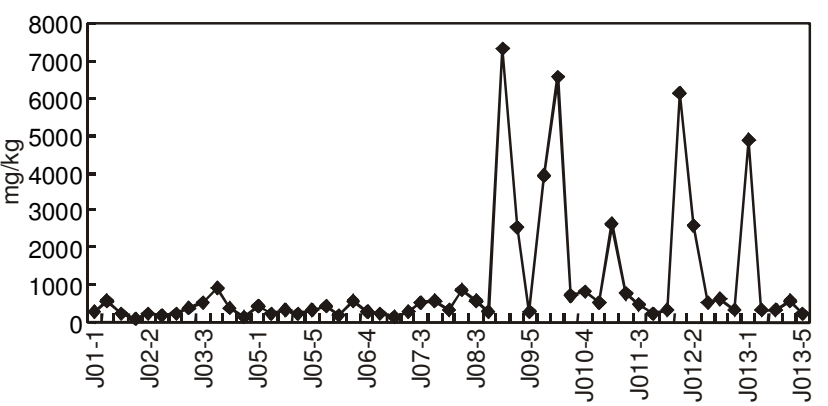

Fig. 4. Total petroleum hydrocarbon concentration in samples

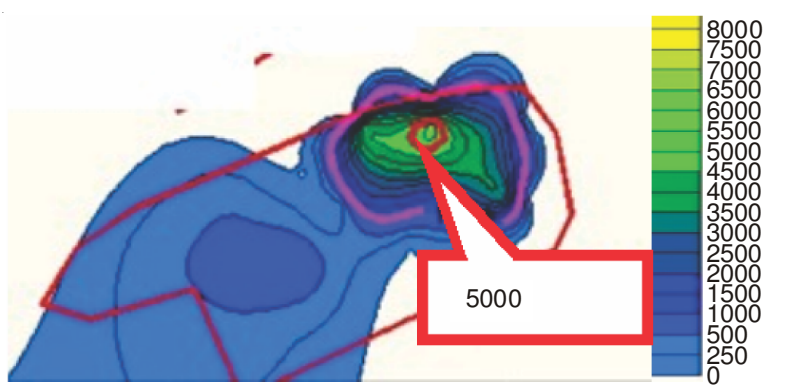

Fig. 5. TPH Pollution condition

hydrocarbon pollution should caused by underground leaking. By the same case, TPH pollution in sample labeled 10 \# and 12 \# would attribute to oil spilling related to oil translation.

The curve is run by surfer according to monitoring data and the TPH contamination extent computed by kriging method (Fig. 4). Furthermore, because of the characteristics of clay soil in this gas station, the scope of TPH contamination might not to enlarge rapidly. Most of the current region was not polluted by TPH. However, the western part in this area was higher than eastern part, maybe the rainfall would enable the TPH move to the other part due to the oil tank locating in western part.

The risk assessment results were as shown in Fig. 6 (Table-4). Most of non-cancer hazard risk was caused by dermal intake, the risk results from direct oral ingestion or inhalation intake was slight. This site would be planning to utilize for residential land use, residents would have great health risk on account of the long-term exposure to total petroleum hydrocarbons. Therefore, site should be remediated before construction.

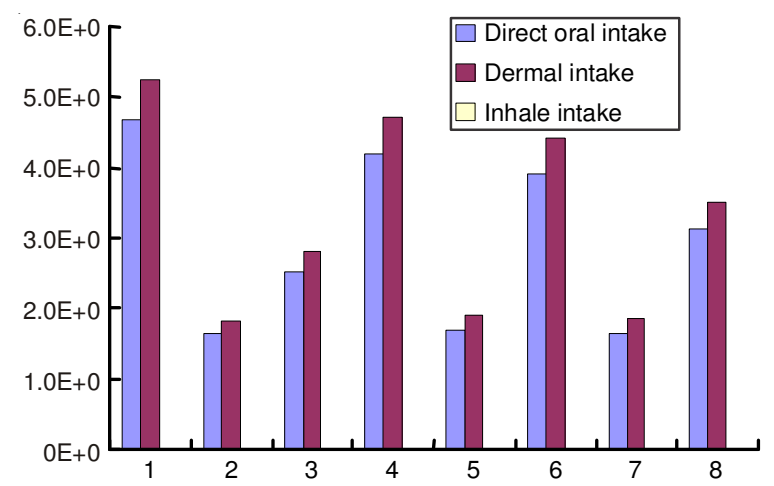

Fig. 6. Non-carcinogenic risks on different ways

\begin{tabular}{cccc} 
TABLE-4 & \\
REFERENCE DOSE OF NON-CARCINOGENIC AT TPH mg/(kg d) \\
\hline Pollutant & Oral intake & Breath intake & Skin intake \\
\hline TPH & 0.02 & 0.0571 & 0.016 \\
\hline
\end{tabular}

\section{Conclusion}

The soil and subsoil in the gas station site were severely polluted by total petroleum hydrocarbon and concentrations of some samples were far beyond the critical value of intervention according to Dutch standard. Oil spilled from tank or oil leaked from underground oil storage must be the main contributing source. The maximum concentration of total petroleum hydrocarbons in soil were $7315 \mathrm{mg} / \mathrm{kg}$ and the gas station contaminated sites would been planning to utilize for residential areas, so the nearby residents would suffer health risks due to exposure to TPH. Site remediation need to be carried out before construction.

\section{REFERENCES}

1. Y.H. Jiang, Y. Li, X.J. Kang, Q.P. Zhou, X. Zhou and Y.P. Zhu, J. Environ. Prot., 3, 49 (2012).

2. C.M. Kao and J. Prosser, J. Hazard. Mater., 82, 275 (2001).

3. H. Lee and Y.-J. Lee, Asian J. Chem., 22, 1535 (2010).

4. M. Zolezzi, C. Cattaneo and J.V. Tarazona, Environ. Sci. Technol., 39, 2920 (2005).

5. R. Iturbe, C. Flores, R.M. Flores and L.G. Torres, Chemosphere, 61, 1618 (2005).

6. R. Iturbe, R.M. Flores, C.R. Flores and L.G. Torres, Environ. Monit. Assessm., 91, 237 (2004).

7. Risk Assessment Guidance for Superfund:Volume I, Human Health Evaluation Manual Part B,Development of Risk-Based Preliminary Remediation Goals (1991). 